\title{
Analysis of student adjustment in dormitory based on type of school, cultural background and grade level
}

\author{
Rusnila $^{1}$, Daharnis ${ }^{1}$, Yarmis Syukur ${ }^{1}$ \\ ${ }^{1}$ Universitas Negeri Padang, \\ *Corresponding author, e-mail: rusnila.adawiyah@gmail.com
}

\begin{abstract}
Adjustment is a process that includes mental and behavioral responses to achieve balance in meeting needs in accordance with environmental demands. However, it was found that students had difficulty adjusting, such as being unprepared to live in a dormitory, having difficulty being away from their parents, violating the dormitory rules, having difficulty getting along, and having intercultural disputes. This is thought to be related to differences in schools, cultural backgrounds and grade levels. This research aims to analyze the adjustment of students in the dormitory based on the type of school, cultural background, and grade level. This research method used is ex post facto with a factorial analysis design. The population was 200 students in the dormitory of Al-Faruqi Kampar, Riau. This research uses a self-adjustment instrument with Alpha Cronbach of 0.876 . The data were analyzed using the technique Analysis of Variance (ANOVA). The results showed that the level of adjustment of students based on the type of school was in the high category and there were significant differences in the adjustment of students based on the type of school, the level of adjustment of students based on the cultural background was high category and there was no significant difference in the adjustment of students based on cultural background. The level of adjustment based on grade level high category and there is no significant difference in adjustment based on grade level, and there is no interaction between these variables in explaining the adjustment of students in the dormitory. The implications of the results of this research can be used as a reference for counselors in schools for the preparation of guidance and counseling service programs to improve student adjustment in dormitories.
\end{abstract}

Keywords: Adjustment, Type of School, Cultural Background, Grade Level

How to Cite: Rusnila, R., Daharnis, D., \& Syukur, Y. (2021). Analysis of student adjustment in dormitory based on type of school, cultural background and grade level. International Journal of Research in Counseling and Education, 5 (1): pp. 62-69, DOI: https://doi.org/10.24036/00417za0002

\section{Introduction}

A boarding school is an educational institution, which requires all learners or better known as students to live and settle in the dorms to complete their education. Islamic boarding schools are certainly different from other school dormitories so that every student is required to be able to adapt to all existing activities cultures, and habits, and obey all applicable activities and regulations to create a harmonious and conducive environment.

Self-adjustment is an effort made by individuals in overcoming various pressures and demands, as well as the ability to achieve a balance in meeting their own needs with the demands of the environment in which they live (Anisa, Yusmansyah \& Utaminingsih, 2017). Schneiders argues that self-adjustment is a process that includes mental and behavioral responses which are an individual's effort to successfully overcome the needs, tensions, conflicts, and frustrations experienced within him. The individual effort aims to obtain harmony and harmony between the demands in oneself and what is expected by the environment (Ghufron \& Risnawati, 2010).

Based on the statement above, it can be concluded that self-adjustment is a process that includes mental responses and individual behavior to meet their own needs and demands in the environment in which they live. The process of self-adjustment carried out by individuals aims to gain balance with their new environment. Living in a dormitory environment, students will get to know many people with different backgrounds, be it 
family, region, culture, language, education, or economic level (Komar \& Putra, 2018). students are also required to live independently (Oktari \& Kosasih, 2019), and away from parents and family (Thohiroh, Novianti \& Yudiana, 2019). One of the factors that influence self-adjustment is the environment, peers, and cultural background (Ali \& Asrori, 2011; \& Widiasavitri, 2016), therefore students must be able to adapt themselves well (Zakiyah, Hidayati \& Setyawan, 2010).

Adjustment in the process tends to bring a feeling of inability to cope with the new changes in living her life (Ward, Bochner \& Furnham, 2020), giving to rise various problems, such as conflicts, stress, and frustration to cause stress (Winkel \& Hastuti, 2007). Facing all these problems, some individuals can adapt well, but some experience difficulties (Wulandari \& Rustika, 2016; Fernández, Araújo, Vacas, Almeida \& González, 2017). Individuals who can adapt themselves well will more easily overcome the problems they face, have a calm attitude, can neutralize tension, can communicate well with others (Aristiani, 2016), accept new people around them, feel comfortable with themselves, and act mature and tend not to rush (Goleman \& Daniel, 2009). Meanwhile, individuals who have difficulty adjusting will experience failure to build social relationships with others, channel emotions in negative ways, feel unappreciated, have difficulty making decisions, blame themselves, feel intimidated (Ward, Bochner \& Furnham, 2020), make incorrect behavior patterns (maladjustment) (Fatimah, 2008) and can trigger various obstacles in the academic process or during the learning process (Arifin, Dardiri \& Handayani, 2016). Therefore, the adjustment is important owned by each student, because it will determine how the ability to live life in a dormitory on semesters later (Semaraputri, 2018), forming a strong personality (Candrawati, 2019), and the creation of mental health or mental individual ( Ayun, 2018).

The problem of adjustment as described above is also experienced by students who live in the dormitory school at Al-Faruqi Kampar, Riau, which requires all students to live and stay in the dormitory while carrying out the educational process until graduation. The obligation to live in a dormitory requires students to be able to adapt to all activities, cultures, and habits that exist in the pesantren environment and to obey all existing activities and regulations. While in the dormitory, there were several adjustment problems experienced by students. Students who have just lived in the dormitory often feel unable to be away from their parents, feel uncomfortable, unable to follow lessons well, feel unable to participate in all dormitory activities, do not fit in with new friends both in the room and between grade levels, disputes with friends between schools and disputes caused by cultural differences.

Based on the problems above, it is necessary to take action or efforts to improve student adjustment in the dormitory. In this case, cooperation between the hostel supervisor and the school counselor is very necessary (Sari, Neviyarni \& Syukur, 2021). Guidance and counseling as part of the education component provide several services provided by counselors to students to be able to actualize their potential and achieve optimal development. Counselors in schools need to optimize the areas of personal and social development, with the hope that students in dormitories can adjust well while living their lives in dormitories. This is with the consideration that while in the dormitory students need to adjust to their new living environment, adjust to the learning process, the rules that exist in the dormitory, adjust to the hostel supervisor, teachers, and peers so that the educational process goes well and get better results too.

There are many research on the problem of student adjustment in boarding schools. However, no research has been conducted with adjustment variables with a specific demographic focus. The focus of this research is the analysis of student adjustment in the dormitory based on the type of school, cultural background, and grade level.

\section{Method}

\section{Research Design}

Type of research is a descriptive comparative quantitative method with a factorial analysis design. The research design uses a factorial analysis design ex post facto $2 \times 2 \times 3$. This research involves more than two groups and one independent variable aims to compare the data obtained, namely the adjustment of students in the dormitory based on the type of school, cultural background and grade level.

\section{Participant}

Data in this research were collected through the administration of the adjustment instrument. Before data collection was conducted prior weighing process (judgment) by engaging three experts into expert judgment. The feasibility of the research instrument was carried out by testing the instrument involving 50 respondents. Then the data collection stage involved 200 students who lived in the dormitory at Al-Faruqi. 


\section{Measurement}

The process of collecting data is done by administering the instrument to the respondents. The instrument used in this study is a self-adjustment instrument using a type Likert. The consists of item numbers, statements, and includes five alternative answer choices, namely: very appropriate, appropriate, quite appropriate, not appropriate, and very inappropriate.

The development of the instrument is carried out in steps, namely conducting a literature review to examine the concepts or variables to be measured, determining the indicators for each variable according to the theories and views of experts, making a grid-based on indicators, compiling and reviewing the suitability of the items. statement with an instrument grid, as well as compiling instructions for filling out research instruments. Then, the process of weighing (judgment) by a competent expert for the variables of this research.

To measure the feasibility of the instrument, then the instrument is tested. The level of feasibility in question is to measure the validity and reliability of the instrument. The results of the measurement of the selfadjustment instrument were 36 statement items and overall were declared valid, while the results of the measurement of the instrument's reliability level, the value Alpha Cronbach of students' self-adjustment in the dormitory was 0.876 . Therefore, it can be concluded that the research instrument is reliable.

After the feasibility test of the research instrument was carried out, the data collection process was carried out by administering the instrument to the respondents. Data collection was carried out by preparing complete self-adjustment instruments, determining data sources such as respondents and the required documents, as well as collecting data system according to what had been previously planned.

Before analyzing the research data, the analysis requirements test was carried out, namely the normality test and the data homogeneity test. The requirements analysis test is carried out as a basis for consideration for selecting and determining the type of data analysis that will be used in testing research hypotheses. Furthermore, carried outdated analysis of students' adjustment in the dormitory was using the Analysis of Variance (ANOVA).

\section{Data Analysis}

Testing the requirements of data analysis was carried out by normality test using the Kolmogorov Smirnov test with a P-value of 0.05 . The normality test will determine whether the data comes from a normally distributed population or not. Then the homogeneity test was carried out using the test Bartlett with P- value 0.05. The test was conducted to determine whether all groups of variables had the same or homogeneous variance. After testing the data analysis requirements, hypothesis testing is then carried out to see the differences in student adjustment based on several independent variables using Analysis of Variance (ANOVA).

\section{Results}

\section{Data Description}

The data obtained are arranged in a table that describes the respondent's data in predetermined categories and is then described in percentage values (\%). The data can be seen in the following table.

Table 1. Description of Student Adjustment by Type of School, Cultural Background and Grade Level

\begin{tabular}{|c|c|c|c|c|c|c|c|}
\hline $\begin{array}{l}\text { Type of } \\
\text { School }\end{array}$ & Culture & $\begin{array}{c}\text { Grade } \\
\text { Level }\end{array}$ & Mean & $\mathbf{n}$ & SD & $\%$ & K \\
\hline \multirow{8}{*}{$\begin{array}{c}\text { Junior High } \\
\text { School }\end{array}$} & \multirow{4}{*}{ Malay } & Class I & 139.66 & 41 & 13,685 & 78 & $\mathrm{~T}$ \\
\hline & & Class II & 138.75 & 20 & 8,735 & 77 & $\mathrm{~T}$ \\
\hline & & Class III & 139.82 & 11 & 12032 & 78 & $\mathrm{~T}$ \\
\hline & & Total & 139.43 & 72 & 12104 & 77 & $\mathrm{~T}$ \\
\hline & \multirow{4}{*}{ Non-Malay } & Class I & 135.65 & 31 & 11227 & 75 & $\mathrm{~T}$ \\
\hline & & Class II & 139.07 & 15 & 11640 & 77 & $\mathrm{~T}$ \\
\hline & & Class III & 141.38 & 8 & 11211 & 79 & $\mathrm{~T}$ \\
\hline & & Total & 137.44 & 54 & 11345 & 76 & $\mathrm{~T}$ \\
\hline \multirow{8}{*}{$\begin{array}{l}\text { Vocational } \\
\text { High School }\end{array}$} & \multirow{4}{*}{ Malay } & Class I & 139.71 & 14 & 12332 & 78 & $\mathrm{~T}$ \\
\hline & & Class II & 141.72 & 18 & 13,429 & 79 & $\mathrm{~T}$ \\
\hline & & Class III & 130.38 & 16 & 9387 & 72 & $\mathrm{~T}$ \\
\hline & & Total & 137.35 & 48 & 12687 & 76 & $\mathrm{~T}$ \\
\hline & \multirow{4}{*}{ Non-Malay } & Class I & 136.91 & 11 & 11777 & 76 & $\mathrm{~T}$ \\
\hline & & Class II & 132.63 & 8 & 11649 & 74 & $\mathrm{~T}$ \\
\hline & & Class III & 129.43 & 7 & 10114 & 72 & $\mathrm{~T}$ \\
\hline & & Total & 133.58 & 26 & 11,314 & 74 & $\mathrm{~T}$ \\
\hline
\end{tabular}

(Analysis of student adjustment in dormitory based on type of school, cultural background and grade level) 


\begin{tabular}{|c|c|c|c|c|c|c|c|}
\hline $\begin{array}{l}\text { Type of } \\
\text { School }\end{array}$ & Culture & $\begin{array}{l}\text { Grade } \\
\text { Level }\end{array}$ & Mean & $\mathbf{n}$ & SD & $\%$ & K \\
\hline \multirow{8}{*}{ Total } & \multirow{4}{*}{ Malay } & Class I & 139.67 & 55 & 13,241 & 78 & $\mathrm{~T}$ \\
\hline & & Class II & 140.16 & 38 & 11,149 & 78 & $\mathrm{~T}$ \\
\hline & & Class III & 134.22 & 27 & 11352 & 75 & $\mathrm{~T}$ \\
\hline & & Total & 138.60 & 120 & 12.330 & 77 & $\mathrm{~T}$ \\
\hline & \multirow{4}{*}{ Non-Malay } & Class I & 135.98 & 42 & 11241 & 76 & $\mathrm{~T}$ \\
\hline & & Class II & 136.83 & 23 & 11.800 & 76 & $\mathrm{~T}$ \\
\hline & & Class III & 135.80 & 15 & 12.031 & 75 & $\mathrm{~T}$ \\
\hline & & To tal & 136.19 & 80 & 11410 & 76 & $\mathrm{~T}$ \\
\hline
\end{tabular}

*Note: SD: Standard Deviation, K: Criteria, T: High

Based on Table 1, it is understood that the level of adjustment of students in dormitories by type of school, cultural background, and level of the overall classification at the high category $(T)$. The average (mean) of the highest self-adjustment is a junior high school student with a Malay cultural background in class III with an average score of 139.82 in the high category $(\mathrm{T})$, with an achievement of $78 \%$ of the ideal score; and the lowest average adjustment is Vocational High School students with non-Malay cultural backgrounds in class III with an average score of $129.43(\mathrm{~T})$, with an achievement of $72 \%$.

\section{Normality Test}

The results of the data normality test using the method Kolmogorov Smirnov with a level if Sig. greater than 0.05, it means the data is normal. From the results of the normality test for students' adjustment in the dormitory based on the type of school, namely Junior High School, it was obtained Sig. of 0.088, the type of school, namely Vocational High School, obtained Sig. as big as $0.200^{*}$, Malay cultural background obtained by Sig. of 0.060 , based on the non-Malay cultural background obtained Sig. of $0.200^{*}$, based on the level of class I obtained Sig. of $0.200^{*}$, based on the level of class II obtained Sig. of $0.200^{*}$ and based on the level of class III obtained Sig. of $0.200^{*}$. Thus, it can be concluded that the data on students' self-adjustment based on the type of school, cultural background, and grade level were normally distributed.

\section{Homogeneity Test}

The results of the homogeneity test used the test Bartlett at the alpha $(\alpha) 0.05$ limit. The results of the homogeneity test of student adjustment data in the dormitory based on the type of school obtained sig. of 0.690 , cultural background of 0.723 , and grade level of 0.733 . Thus, it can be concluded that the adjustment data based on all sample groups have the same or homogeneous variance.

Table 2. Analysis of Variance (ANOVA) Data for Student Self-Adjustment Scores

\begin{tabular}{|c|c|c|c|c|c|c|}
\hline Sub variance & JK & dk & Rk & $F_{\text {count }}$ & Sig & Interpretation \\
\hline $\begin{array}{c}\text { Scores of Junior High School } \\
\text { and Vocational High School } \\
\text { students }\end{array}$ & 591.058 & 1 & 591.058 & 4,231 & 0.041 & Significant \\
\hline $\begin{array}{l}\text { Score of Malay culture Non- } \\
\text { Malay students }\end{array}$ & 239.646 & 1 & 239.646 & 1.716 & 0.192 & Not Significant \\
\hline $\begin{array}{c}\text { Scores of students of class I, II } \\
\text { and III }\end{array}$ & 222.411 & 2 & 111.206 & 0.796 & 0.453 & Not Significant \\
\hline $\begin{array}{l}\text { Interaction variable of the } \\
\text { type of school and cultural } \\
\text { backgrounds }\end{array}$ & 122.331 & 1 & 122.331 & 0.876 & 0.351 & Not Significant \\
\hline $\begin{array}{l}\text { Interaction variable of the } \\
\text { type of school and grade level } \\
\text { interactions cultural }\end{array}$ & 825.580 & 2 & 412.790 & 2.955 & 0.054 & Not Significant \\
\hline $\begin{array}{l}\text { background variables and } \\
\text { grade level }\end{array}$ & 132.145 & 2 & 66.073 & 0.473 & 0.624 & No Significant \\
\hline $\begin{array}{l}\text { Interaction variable of the } \\
\text { type of school, cultural } \\
\text { background and grade levels }\end{array}$ & 219.725 & 2 & 109.863 & 0.786 & 0.457 & Not Significant \\
\hline
\end{tabular}

The results of the analysis of variance (ANOVA) in Table 2 can be understood that the adjustment of students in the dormitory in terms of the type of junior high school and vocational school, shows that there are 
significant differences, which means that the type of school determines the adjustment of students. While the adjustment of students in the dormitory in terms of cultural background and grade level there is no significant difference, which means that the cultural background and grade level do not determine the adjustment of students in the dormitory. In terms of interaction, there is no significant interaction between the type of school, cultural background and grade level in determining the adjustment of students in the dormitory.

\section{Discussion}

\section{Analysis of Student Adjustment in Dormitory Based on Types of Junior High School and Vocational High School and the Differences}

The results of the data analysis of student adjustment in dormitories by type of school, namely the level of adjustment of Junior High School and Vocational High School students are in the high category (T). When viewed in detail from the results of the analysis, the adjustment data of junior high school students on average is higher than that of vocational high school students. This means that there is a significant difference in students' self-adjustment based on the type of school. This difference in self-adjustment can be seen from the average value obtained from all existing sub-variables, which explains that Junior High School students have higher abilities than Vocational High School students. This shows that not all students can easily adjust themselves in the dormitory.

Based on the results of the study explaining that the adjustment of students in junior high school is in the high category, this shows students in junior high school have a better ability to adjust themselves in the dormitory. Students who are able to adapt well show a calm attitude, get along and communicate well, accept new people around them, feel comfortable with themselves, and act mature and tend not to be in a hurry (Goleman, 2009; Adiningtiyas, 2015). Good adjustment can be achieved if the life that is lived is completely free from pressure, shock and acute mental tension, is able to face difficulties in an objective way, and can enjoy life in a stable, calm, happy and accomplished way (Fatimah, 2008). .

One of the factors that support students in Junior High School having good adaptability is due to the support from peers in the dormitory, feeling excited about entering a new life and meeting new people in their lives. This is also supported by the number of educators and supervisors in dormitories as well as more students in junior high schools. The fulfillment of the needs available in the dormitory can also be one of the determining factors for students in adjusting themselves, such as comfortable rooms, complete facilities and easy access for students to reach the study building, mosque and school canteen.

In addition, support from the family is also considered to create a good adjustment for students. This is in accordance with the opinion which explains that if an individual is raised in a family where there is security, love, respect, tolerance and warmth, it can affect the ability to adapt to new things in life. This can also foster confidence and self-ability to do new tasks and roles (Wijaya, 2012).

Meanwhile, according to the results of research that has been done, it shows that students in Vocational High Schools have lower self-adjustment. The low level of adjustment of students in Vocational High Schools compared to students in Junior High Schools is caused by several factors such as differences in dormitories, facilities, activities, and more demands. So that students in Vocational High Schools are expected to continue to adapt themselves well. In addition, there are also factors that affect the ability to adapt, such as differences in developmental tasks for each student.

Humans as individuals essentially continue to grow and develop throughout their lives. Individuals go through a series of developmental stages starting from childhood to old age. Each stage of development cannot be said to be a discontinuous stage, but rather a close relationship and mutually influence one another (Hurlock, 2002). The developmental tasks at each stage are different, so that individuals are faced with changes that do not only come from biological aspects but also cognitive, environmental and socio-emotional aspects. The ability to adapt is very necessary because it can help individuals face and overcome various changes, demands and even problems at each stage (Agustiani, 2009).

Various transitions at each stage of development that are passed by individuals, one of which is the school transition. The transition to entering high school from junior high school, there are many changes that occur not only in the self but also in the family environment. This can create a difficult situation, as it involves issues related to social change, increased responsibility and decreased dependence on parents. Individuals also enter a larger school structure, a change from a small group of friends to a larger group of friends and an increased focus on achievement and performance (Santrock, 2007). Thus, having the ability to adjust for students in Vocational High Schools is very important in order to be able to face changes, especially in dormitories.

If seen from the results of descriptive statistics of student self-adjustment based on school type, cultural background and grade level in Table 7,junior the average (mean) of the highest self-adjustment is students high 
school with Malay cultural background grade III with an average of 139.82 are in category (T), with an achievement of $78 \%$. This means that students in Junior High School have the ability to adjust well in the dormitory. Meanwhile, the lowest self-adjustment average students at Vocational High School with non-Malay cultural backgrounds in class III with an average score of 129.43 with an achievement of $72 \%$. This means that there are still students in Vocational High Schools who have not been able to adjust themselves well in the dormitory.

There are differences in the adjustment of students in Junior High School with students in Vocational High School and the importance of improving and developing student self-adjustment, it is necessary to collaborate with counselors in schools. Cooperation is carried out to improve and develop students' self-adjustment considering aspects of self-adjustment by optimizing the ability to adapt to the environment, having satisfying relationships, complying with applicable rules and norms, changing attitudes and behavior, ability to make plans, organizing self-response, understanding differences. each individual and the ability to respond to problems.

Improving and developing the ability to adjust in the dormitory can be done by implementing guidance and counseling services that are supported by approaches in counseling. In this case, the researcher suggests a counseling approach that can be used, namely the group format reality counseling approach.

The group format reality counseling approach is carried out with the aim of inviting students to raise awareness of the importance of having good self-adjustment by evaluating themselves, exploring and assessing student behaviors, especially irresponsible behavior that results in low adjustment in the dormitory. The materials that can be provided in the service implementation process are improving self-adjustment, increasing emotional intelligence, self-management and improving discipline.

\section{Analysis of Student Adjustment in Dormitory Based on Malay and Non-Malay Cultural Backgrounds and Differences}

The results of the analysis of student adjustment data in dormitories based on Malay and Non-Malay cultural backgrounds show that the level of adjustment of students is in the high category ( $T$ ), and there is no significant difference between the two. This means that santi in the Al-Faruqi Islamic boarding school is able to adapt well to various differences in the dormitory and cultural differences do not determine students' adjustment. The ability to adapt to various cultural differences is a form of individual success in adjusting to other individuals or with their groups. Individuals who are able to adapt well will easily establish relationships with other people and have fun (Azizah \& Hidayati, 2015).

Students who are able to adapt themselves show an easy-going attitude, have good relationships with others, are able to regulate emotions well and accept any differences in the dormitory. This is in accordance with the opinion that individuals who are able to adapt well generally have the characteristics of having good interpersonal relationships, having good communication with others and being liked by many people (Agustiani, 2006). Instilling socio-cultural values in life will also have an impact on achieving better learning outcomes (Hasgimianti, Nirwana \& Daharnis, 2017).

One of the factors that support students being able to adjust to cultural differences in the dormitory is a satisfying relationship with their new environment, the ability to manage emotions, the ability to organize selfresponses and be able to understand each individual difference. In accordance with the opinion that reinforces that self-adjustment can be influenced by how the individual tends to determine his attitude. Individuals who are positive about everything they face will have a greater opportunity to be able to adjust well (Siregar \& Kustanti, 2020).

Based on the results of the study which stated that students in the Al-Faruqi boarding school dormitory have good abilities in adjusting themselves, this needs to be improved and developed. Dormitory supervisors can collaborate with counselors at schools to carry out guidance and counseling services. Counselors in schools can carry out guidance and counseling services by providing appropriate materials, so that they can help improve and develop students' abilities to better adapt themselves in the dormitory.

In order for the implementation of guidance and counseling services by counselors to obtain more optimal results, it can be supported by approaches in counseling. One of the approaches suggested by the researcher is the group format reality counseling approach. The implementation of group format reality counseling is carried out with the hope that students can easily assess their behavior in the dormitory, and can plan appropriate actions with various differences in the dormitory.

\section{Analysis of Student Adjustment in Dormitory Based on Grades I, II and III and Differences}

The results of the analysis of student adjustment data in dormitories based on grade level showed that the level of student adjustment was in the high category $(\mathrm{T})$. When viewed from the results of the average score 
obtained from each class, there are differences in the average scores between class I, II and class III, but there is no significant difference. This means that every student in the Al-Faruqi boarding school is able to get along and interact well without discriminating between students.

Adjustment in the process, some are able to adjust themselves well and some have difficulty (Susanti, Yusuf \& Firman, 2019).In order to adapt well, supporting factors are needed (Fitria, Marsidin \& Nirwana, 2014), one of which is peer support (Ali \& Ansori, 2015).

One of the factors that can influence students to be able to adjust well is the environmental conditions of their peers in a peaceful, safe and peaceful dormitory. Conditions like this can make students feel comfortable and encouraged to interact with other students without feeling threatened. This is reinforced by the opinion that peers can be a means for individuals to share, provide input and provide mutual support (Ali \& Asrori 2015), such as positive attention and encouragement and a sense of caring when experiencing a problem (Bulmer, 2015).

Based on the results of the study that students in the Al-Faruqi boarding school dormitory have good adjustments to their fellow students in the dormitory, this needs to be improved and developed. Therefore, it is necessary to have a counselor role in schools. Counselors can carry out guidance and counseling services supported by approaches in counseling, one of which is the group format reality counseling approach. The implementation of group format reality counseling is carried out by optimizing indicators of self-adjustment, such as a satisfactory relationship with the environment, the ability to organize a self-response and the ability to understand individual differences.

\section{Analysis of Student Adjustment in Dormitory Based on Type of School, Cultural Background and Grade Level and Interaction Between Variables in Explaining Student Adjustment.}

The results of the data analysis of student adjustment in the dormitory based on the type of school, cultural background and grade level were in the high category $(\mathrm{T})$. The findings can also be concluded that the adjustment of students in the dormitory based on the interaction between the variables of school type and cultural background, type of school and grade level as well as between variables of school type, cultural background and grade level showed no significant interaction.

Having a good relationship with the various differences in each individual, be it school, culture, grade level and other differences in every life, can help students adjust to their new environment, especially in the dormitory (Roskell, 2013). Implementation of guidance and counseling services that are supported by approaches in counseling in this case is very necessary, so that it can become a forum for students to improve and develop better adjustments in the dormitory.

\section{Conclusion}

After analyzing, testing hypotheses and being studied and described in the discussion, it can be concluded that the data or findings in this study are the level of student adjustment based on the type of school (Junior High School and Vocational High School) in the high category (T) and there are significant difference in students' adjustment to dormitories by type of school. The level of adjustment of students based on cultural background, culture (Malay and Non-Malay) and grade level (I, II and III) are in the high category (T) and there is no significant difference in the adjustment of students in the dormitory based on background culture and grade level, and there is no interaction between school type, cultural background and grade level in explaining student adjustment. Based on the results of this study, it is necessary to have a counselor role in schools to carry out guidance and counseling services. The implementation of guidance and counseling services aims to be able to improve and develop students' self-adjustment in the dormitory.

\section{References}

Adiningtiyas, S. W. (2015). Hubungan kecerdasan emosi dengan penyesuaian diri siswa di sekolah. KOPASTA: Jurnal Program Studi Bimbingan Konseling, 2(2), 91-96.

Ali, M., \& Asrori, M. (2015). Perkembangan peserta didik. Jakarta: Bumi Aksara.

Anisa, R. N., Yusmansyah, Y., \& Utaminingsih, D. (2017). Efektivitas pelaksanaan bimbingan kelompok dengan pendekatan konseling realitas dalam mengembangkan penyesuaian diri siswa di lingkungan sekolah pada siswa kelas X SMAN 1 Sungai Tarab. Jurnal Psikologi Udayana, 5(2), 126.

Arifin, M., Dardiri, A., \& Handayani, A. N. (2016). Hubungan kemampuan penyesuaian diri dan pola berpikir dengan kemandirian belajar serta dampaknya pada prestasi akademik mahasiswa. Jurnal Pendidikan: Teori, Penelitian, dan Pengembangan, 1(10), 1943-1951.

Aristiani. R. (2016). Meningkatkan percaya diri siswa melalui layanan informasi berbantuan audiovisual. Jurnal

(Analysis of student adjustment in dormitory based on type of school, cultural background and grade level) 


\section{Konseling Gusjigang, 2(2), 182-189}

Ayun, Q. (2018). Depresi sebagai dampak kegagalan penyesuaian diri pada mahasiswa. Unit Pelaksana Teknis Bimbingan dan Konseling \& Pengembangkan Karir (UPT-BKPK) Universitas Pendidikan Indonesia (UPI), 225-241

Candrawati, D. (2019). Persepsi terhadap pola asuh demokratis dan konsep diri terhadap penyesuaian diri pada mahasiswa. Psikostudia: Jurnal Psikologi, 8(2), 99-107.

Fatimah, E. (2008). Psikologi perkembangan: Perkembangan peserta didik. Bandung: Pustaka Setia.

Fernández, M. F. P., Araújo, A. M., Vacas, C. T., Almeida, L. S., \& González, M. S. R. (2017). Predictores del ajuste de los estudiantes durante la transición a la Universidad en España. Psicothema, 29(1), 67-72.

Fitria, R., Marsidin, S., \& Nirwana, H. (2014). Hubungan persepsi siswa tentang budaya sekolah dan motivasi belajar dengan penyesuaian diri siswa. Konselor, 3(4), 139-146.

Ghufron \& Risnawati. (2010). Teori-teori psikologi. Yogyakarta: Ar-Ruzz Media.

Goleman \& Daniel. (2009). Emotional intelligence. Jakarta: Gramedia Pustaka Utama.

Hurlock, E. B. (2002). Psikologi perkembangan. Jakarta: Erlangga.

Hasgimianti, Nirwana, H., \& Daharnis. (2017). Perhatian orangtua dan motivasi belajar siswa yang berlatar belakang melayu dan Jawa. INSIGHT: Jurnal Bimbingan Konseling, 6(2), 130-143.

Komar, A. F., \& Putra, Y. Y. (2018). Hubungan persepsi terhadap senior dengan penyesuaian diri siswa asrama di SMA. Jurnal Riset Psikologi, 2018(4).

Oktari, D. P., \& Kosasih, A. (2019). Pendidikan karakter religius dan mandiri di pesantren. Jurnal Pendidikan Ilmu Sosial, 28(1), 42-52.

Pritaningrum, M., \& Hendriani, W. (2013). Penyesuaian diri remaja yang tinggal di Pesantren Modern Nurul Izzah Gresik pada tahun pertama. Jurnal Psikologi Kepribadian Dan Sosial, 2(3), 134-142.

Roskell, D. (2013). Cross-cultural transition: International teachers' experience of "culture shock." Journal of Research in International Education, 12(2), 155-172.

Sari, A. K., Neviyarni, S., Ahmad, R., \& Syukur, Y. (2021). Urgensi kerjasama personil bimbingan konseling di sekolah. 5(1), 30-39.

Semaraputri. (2018). Peran problem focused coping dan konsep diri terhadap penyesuaian diri pada remaja akhir yang menjadi pengurus organisasi kemahasiswaan di Fakultas Kedokteran Universitas Udayana. Jurnal Psikologi Udayana, 5(01), 35.

Susanti, A. Y., Yusuf, A. M., \& Firman, F. (2019). Self-Adjustment and social conflict of multicultural students. International Journal of Applied Counseling and Social Sciences, 1(1), 48-53.

Susanto, Y., \& Indrawati, E. S. (2019). Hubungan antara dukungan teman sebaya dengan penyesuaian diri pada siswa asrama SMA Virgo Fidelis Bawen (Doctoral dissertation, Undip).

Thohiroh, H., Novianti, L. E., \& Yudiana, W. (2019). Peranan Persepsi Dukungan Sosial terhadap Kesejahteraan Subjektif di Sekolah pada Siswa Pesantren Modern. Psympathic : Jurnal IImiah Psikologi, 6(2), 131-144.

Tricahyani, I. A. R., \& Widiasavitri, P. N. (2016). Hubungan antara dukungan sosial dengan penyesuaian diri pada remaja awal di Panti Asuhan Kota Denpasar. Jurnal Psikologi Udayana, 3(3), 542-550.

Ward, C., Bochner, S., \& Furnham, A. (2020). Sojourners: International students. In The Psychology of Culture Shock. Routledge.

Winkel, W. S., \& Hastuti, M. S. (2007). Bimbingan dan konseling di institusi pendidikan. Media Abadi.

Wulandari, N. K., \& Rustika, I. M. (2016). Peran kemandirian dan kecerdasan emosional terhadap penyesuaian diri pada siswa asrama tahun pertama SMK Kesehatan Bali Medika Denpasar. Jurnal Psikologi Udayana, 3(2), 232-243. 